\title{
State-Funded Activism: Lessons from Civil Society Organizations in Ireland
}

\author{
ANNA M. VISSER \\ University College Dublin, Ireland
}

\begin{abstract}
Civil society organizations (CSOs) in Ireland receive significant state funding and institutional support according to the logic that they are important contributors to democratic governance, with the effect that the CSO sector has expanded and become more embedded in formal decision-making processes over the past several decades. At the same time, dependency on government funding exposes CSOs to three important challenges: to stay true to activist mandates in the face of pressure from state funders to focus on service provision; to maintain accountability to constituents while also satisfying the vertically oriented accountability requirements of the state; and to nurture collaboration among CSOs in a context of competition for state funding. University-based activists, who are also reliant on (increasingly scarce) government funding, face similar challenges, and therefore should pay more attention to debates regarding state funding in the CSO sphere. By working together to overcome common challenges associated with state funding, activists in both spheres can more effectively contribute to progressive social change.
\end{abstract}

KEYWORDS civil society; democracy; activism; state funding

\section{Introduction}

Over the 15 years I have worked in Irish Civil Society Organizations (CSOs), state funding - and especially the strings attached to it - has been a frequent focus of criticism from inside and outside the CSO sphere, as well as a dominant theme for self-reflection within CSOs. Therefore, when I returned to university for doctoral studies, I looked forward to engaging with scholarly perspectives on state funding for CSO-activism in order to deepen my own understanding of how, as activists, we can balance the allure of state funding with a rigorous assessment of its risks. I was surprised to discover that despite studies detailing how such funding can support pro-democracy anna@annavisser.ie 
activism (Geller \& Salamon, 2007; Minkoff, 2002; Sawer \& Jupp, 1996) the academic literature as a whole dismisses the possibility that CSOs can maintain their independence or critical voice in the context of financial reliance (e.g., Diamond, 1999; Snowdon, 2012). Much of the literature takes a dim view of CSOs' pro-democratic potential more generally, representing it as corrupted through various forms of complicity with state and private interests (Edwards, 2009, p. 94; Fernando \& Heston, 1997; Lang, 2013, p. 5; Mair, 2005, p. 4; Pyles, 2009).

The literature seems not to be sufficiently aware of the nuanced perspectives on state funding within the CSO world, nor of the irony that authors' capacity to develop their critique (also a form of pro-democracy academic activism) is itself enabled by state funding through the public university system, and therefore vulnerable to the same critique. As I explored the literature further, I discovered that academic analyses of public funding for CSO-activism have developed in relative isolation from a sizable literature on the implications of state support for academic-activism (Butler \& Mulgan, 2013; Calhoun, 2009; Croteau, 2005; Flood, Martin \& Dreher, 2013; Suzuki \& Mayorga, 2014), as well as from relevant debates within the CSO sphere. This strikes me as a missed opportunity, as the two spheres of activism encounter similar challenges with regard to their dependency on state financial support and - I would argue - share potential to learn from each other. In light of this missed opportunity, and in the context of my own background as a CSO-activist, my aim in this article is to outline some key insights from the experience of state-funded CSO-activism in Ireland, which I think can help academic-activists negotiate their own conflicted reliance on public funding. The Irish case may be especially instructive for this purpose, because domestic CSOs are widely understood as having an important democratizing function, and many of them receive substantial state funding.

My argument unfolds in three sections. In the first section I summarize the main ways that activists contribute to strengthening democracy in Ireland, thereby justifying public funding for their activities. I then outline the manner and extent of the Government of Ireland's formal recognition of and support for the democratizing role of CSOs. The second section identifies three challenges that attend Irish CSOs' significant reliance on funding from the public purse, including (a) the risk that strings attached to state funding may divert CSOs from core activist mandates, (b) the risk that accountability will flow upward to government funding agencies, rather than downward to the constituencies CSOs are designed to serve, and (c) the risk that the progressive impact of the CSO sector as a whole will be diminished as organizations compete with one another for funding rather than collaborate to support social change. The third and concluding section argues that these challenges are also relevant to the sphere of university-based activism, and that both CSO- and university-based activists are likely to be more effective agents of social change if they recognize their common challenges and work together to overcome them. 


\section{The Democratic Case for State-funded CSO-Activism in Ireland}

Activists operating in - and often collaborating across - the parallel spheres of academia and CSOs share the key objective of promoting fundamental social change (Croteau, 2005, p. 38), often by contributing to the conditions in which political equality and democracy can flourish. In Ireland, activists in each of these spheres attempt to achieve this democracy-nourishing contribution in four main ways: (a) by monitoring the state, its democratic practices, and the implementation of its domestic and international commitments; (b) by raising awareness about broader societal conditions, such as inequality, which may impact the quality of democratic participation by stifling the involvement of some social groups (Shaver, 2014, p. 1; Wampler, 2008, p. 72); (c) by providing the public with information and analysis, and creating opportunities for citizens to debate and reflect on issues of concern (Butler \& Mulgan, 2013; Dahl, 1989, p. 339; Post \& Rosenblum, 2002 , p. 498), thereby empowering citizens to engage with and challenge the government; and (d) by contributing their expertise regarding the circumstances of marginalized communities to policy debates (Coelho \& Von Lieres, 2010, p. 11; Shaver, 2014, p. 9).

Given the significant challenges facing all democratic states in terms of legitimacy and accountability to their citizens (Carter \& Stokes, 2002; Keane, 2012; Smith, 2009), these are arguably goals that merit state financial support. Indeed, in a situation where political and economic elites can use their significant financial resources to influence political decision-making, it is difficult to imagine how marginalized groups can be fully or equally integrated into democratic processes without social activism being supported substantially by the state, including via funding CSOs that work with specific marginalized communities (Baker, Lynch, Cantillon \& Walsh, 2009, p. 116). Of course, state funding presents both academic and CSO-activists with the challenge of maintaining operational independence in the face of economic dependency, especially in contexts like Ireland where many activists are highly reliant on public funding (INKEX, 2012).

In recent decades, there has been significant growth in the number of CSOs (commonly referred to as community and voluntary organisations) in Ireland as well as in their degree of formalization (Donnelly-Cox \& Cannon, 2010), which parallels similar trends globally (Edwards, 2009). ${ }^{1}$ Growth of the Irish CSO sector has been accompanied by increasing dependency on public funding (Daly, 2007; Keenan, 2008; Meade, 2012), as well as greater

\footnotetext{
${ }^{1}$ Social partnership is an example of this. In Ireland, the term 'social partnership' generally refers to the national pay agreements between government, employers, trade unions, and since 1996, the so-called 'Community and Voluntary Pillar' (CVP). The CVP is a governmentselected grouping of initially eight, national level CSOs ( Allen 1998, p. 293). In Ireland CSOs are commonly referred to as community and voluntary organizations, hence this pillar's title. When the employers withdrew in 2009, Social Partnership effectively ended (Popplewell 2013, p. 7).
} 
involvement in political decision-making through formalized partnerships with government agencies (Larragy, 2006). As the number of CSOs multiplied, state funding gradually displaced personal giving as their main source of income (Daly, 2007; Keenan, 2008; Meade, 2012). A 2012 survey of domestic 'charities' found that $60 \%$ ranked government and local authorities as their most important funding sources (Grant Thornton, 2012, p. 14), even though long-term growth in state funding of CSOs was followed by a sudden decrease with the onset of the 2008 economic crisis (Prizeman \& McGee, 2009). Harvey (2012, p. 43) calculates that government funding of the community and voluntary sector in Ireland contracted by $35 \%$ from 2008 to 2013 (compared to a decrease of just $2.28 \%$ in total government expenditure during this period). CSOs now find themselves dependent on public funding, which has since 2008 become less generous and less reliable.

Despite the recent austerity-induced claw-back of state CSO funding, the longer-term picture appears to be of a deepening political commitment to CSOs as vehicles for fostering inclusive democratic decision-making (Airey, 2006, p. 7; Keenan, 2008, p. 6). This commitment is most emphatically articulated in the Irish government's 2000 White Paper on a Framework for Supporting Voluntary Activity and for Developing the Relationship between the State and the Community and Voluntary Sector, which provides "formal recognition of the role of the Community and Voluntary sector in contributing to the creation of a vibrant, participative democracy and civil society" (2000, p. 3), and asserts that "the State and the sector each recognize their mutual right to constructively critique each other's actions and policies" (2000, p. 109). Importantly, the White Paper uses the language of state/CSO partnership in fostering democracy to justify government funding of CSOs:

This Government is making it clear by publication of the White Paper that we have moved far beyond the attitude that statutory agencies fund voluntary organisations merely for utilitarian reasons, i.e. to provide services that the State cannot or will not deliver directly itself because of resource constraints. We see the Community and Voluntary sector as essential partners in economic and social development. (2000, p. 5)

Problems with implementing its vision notwithstanding (see Hughes, Clancy, Harris \& Beetham, 2007, p. 441), the White Paper remains the core government policy statement on CSOs (see Department of the Environment, Community and Local Government, 2015, p. 20). Several other policy documents reinforce its articulation of the role played by CSOs in nourishing democratic governance including, for example, social partnership agreements titled Programme for Prosperity and Fairness (2000) and Towards 2016 (2006), as well as the government's formal guidelines for how state bodies should engage with civil society, titled Reaching Out Guidelines (2005). Together, these policies emphasize the importance of CSO involvement in political decision-making and the convention of financing CSOs using 
government funds (Harvey, 2014). ${ }^{2}$ Inclusion of the Community and Voluntary Pillar (CVP) as a partner in various social partnership agreements that were formalized after 1996 has been particularly significant, especially as from the early 2000s CVP members received government grants specifically to resource their involvement in partnership processes (Harvey, 2014, p. 12).

Not surprisingly, much of the Irish CSO literature examines the CVP's involvement in and experience of social partnership (Adshead, 2011; Larragy, 2006; Meade, 2005; Murphy, 2002). Some commentators argue that the price of partnership has been too high for CSOs in terms of dependency on volatile state funding and loss of autonomy to pursue independent activist agendas (Kirby \& Murphy, 2009; Meade, 2005; Murphy, 2009). According to Kirby (2010, p. 16):

It is in the terrain of funding that ... state control is most clearly exercised... The growth in state funding for the community and voluntary sector over the past two decades and the ever greater dependence of the sector on such funding comes therefore at great cost to the sector and to the quality of Irish democracy.

From this perspective, and as discussed in greater detail below, state funding may prevent certain core activities from happening, either directly by contractual limitations or indirectly by incubating self-censorship. It may also undermine internal democratic governance by shifting accountability away from the CSO's constituency, and constrain the potential for collaboration across CSOs by creating competition for funds and access.

Other authors maintain that CSOs have been able to sustain an effective and relatively unconstrained working relationship with the Irish state, as evidenced by a variety of achievements vis-à-vis democratic inclusion and governance (Larragy, 2014). Mike Allen, for example, dismisses arguments that state funding interferes with activism: "some of the commentary around this is, I believe, a little simplistic and assumes a simple trade-off between State resources and the abandonment of radical demands" (2013, p. 72). Recalling his involvement running a national organization working with the unemployed, Allen states, "I do not believe that there is a single point from 1987 to 2000, where we made a significant decision which would have been different if we had not been in receipt of State money" (2013, p. 72). Drawing on a study of four state-funded Irish organizations involved in social partnership arrangements, Larragy (2014) similarly concludes that public

\footnotetext{
${ }^{2}$ It is worth noting that other important policy documents - including the 2003 social partnership agreement Sustaining Progress, the National Economic and Social Council's (NESC) Developmental Welfare State (2005) report, and the report of the Forum on Philanthropy (2011) - neglect fully to address these commitments to CSOs. Moreover, the Charities Act 2009 formalizes a permissive but limited approach to advocacy by charities, allowing them to promote political objectives only insofar as they relate directly to the advancement of their charitable purpose (Breen, 2012, p. 1).
} 
funding of CSOs helps to generate effective working relationships between CSOs and the state, which have resulted in significant policy wins.

The ongoing debate between these two perspectives indicates a healthy awareness within the CSO sector of potentially negative implications of both receiving and losing state funding, and offers insights for those involved in state-funded activism in other contexts, including the academy. In the following section I summarize some of those insights in the form of three key challenges that emerge from Irish CSO-activists' experiences of public funding.

\section{A Cautionary Tale Thrice Told Regarding State-Funding of CSO 'Activism'}

\section{Challenge \#1: Defending Core Activist Roles}

A prominent concern in much of the analysis regarding public financing of CSOs is that the state will use funding as leverage to prevent organizations from fulfilling what they identify as their core activist roles. At its most overt, this may involve the government explicitly directing the CSOs it funds to concentrate on service provision at the expense of activism (Clark, 2011; Edwards \& Hulme, 1996), a phenomenon that several authors have identified in the Irish context (Adshead, 2011; Harvey, 2013; Kirby, 2010; Murphy, 2009). For example, Harvey documents how Section 2.8 of the Service Level Agreement of the Health Service Executive (HSE), Ireland's state body that provides all publicly funded health services, "prohibits the use of funding for any attempt at persuasion in matters of policy or practice" (2014, p. 4). Crowley (2013) suggests that government reluctance to support the activist mandate of CSOs has been particularly evident in reductions of funding for organizations that work with Ireland's indigenous minority Traveller community by $63.6 \%$ between 2008 and 2012, with the effect that "the voice of Travellers has been undermined and their ability to resist these cutbacks has been diminished" (Crowley, 2013, para. 9).

More subtly, state funding may create an environment of 'chilling' or selfcensorship, in which CSOs pre-emptively avoid certain types of activist work for fear that they will jeopardize funding (Balassiano \& Chandler, 2009). Hulme \& Edwards express this chilling effect by way of a medical metaphor:

Rather than a rapid deterioration in the patient's condition, we are witnessing a gradual hardening of the arteries in the NGO world as organisations become more bureaucratic and less prone to take risks or bear the costs of listening to those who they seek to assist. (1997, p. 278)

This too seems evident in the Irish context (Crowley, 2012; Hughes, Clancy, Harris, \& Beetham, 2007). In the same study regarding the HSE's agreements cited above, Harvey (2014) finds that even where CSO funding did not come 
from the HSE, health sector organizations became more hesitant in their public campaigning and advocacy because of HSE prohibitions on certain types of activism. Harvey (2014, p. 34) cites one activist as saying, "it chills and makes you cautious. It promotes behind-closed-doors approaches". It is important for CSOs to resist this 'chilling effect' by choosing funding sources carefully and, if necessary, by refusing certain types of state funding.

\section{Challenge \#2: Protecting Accountability to CSO Constituencies}

A second risk of state funding is that it will distort the internal democracy of CSOs by directing accountability upwards toward the relevant state body and away from the organization's membership (Baur \& Schmitz, 2011; Kamat, 2004). Not only do government funding agencies require upward accountability, but according to McCarthy and Zald (1977, p. 1235), a CSO is likely to be less invested in maintaining accountability to an engaged and supportive membership when it is not reliant on that membership for its financial resources. O'Dwyer and Unerman's (2008) examination of Amnesty Ireland is one of several Irish studies to describe how organizations have become more concerned with reporting to their external funder than to their membership base. Cox is another author to express concern that existing Irish civil organizations have become funding-driven rather than mobilization-driven. In addition, according to Cox (2010, p. 15; italics in original), from the 1990s new organisations have emerged "not on the basis of popular mobilisation around issues but on the basis of funding streams created by the European Union, different government departments or more recently private foundations." Indeed, a recent report commissioned by the Irish CSO sector to consider the future of its public policy advocacy work identifies sustaining a meaningful connection to the social groups it represents as one of the sector's key challenges (Walsh, 2014, p. 30). According to this report, rigorous accountability requires "an ongoing and two-way process where the organisation's agenda is set by the group(s) it represents, and the organisation in turn relays information back to its support base in order to support participation, empowerment and mobilization of those most affected by the issues" (Walsh, 2014, p. 30). It is important for the legitimacy, credibility, and efficacy of CSO-activism that state funding not undermine organizations' accountability to the vulnerable constituencies they serve.

\section{Challenge \#3: Working Together, not Against Each Other}

A third risk that emerges from the experiences of Irish CSO-activists is that competition for state funding can negatively impact relationships among organizations, thus impeding possibilities for effective collaboration across 
CSOs (McCarthy \& Zald, 1977; Wallace, 2004). Collaboration is identified by Irish CSO-activists as a significant ongoing challenge (Walsh, 2014, p. 31 ), and state funding has been linked to a diminution of collaborative capacity in the Irish context. For example, Mary Murphy writes that "as groups became reliant on statutory funding schemes, civil society became increasingly marked by an intense sectoral fragmentation" (2013, p. 115). Effective collaboration among organizations is important for CSO-activism because it enables the sector to emphasize particular shared activist themes or issues, allows organizations to maximize impact by pooling resources, and helps to protect individual activists or CSOs from potential state or public censure. Moreover, Wallace (2004, pp. 2-3) argues that campaigning (a core activist activity) is weakened by lack of collaboration between organizations as the CSO sector struggles to move beyond specific sectoral issues toward a broader analysis of social change. The Irish experience suggests that building collaboration among CSOs and nurturing cooperative activism are key challenges in a context of competition for resources, particularly where those resources are decreasing.

\section{The Moral of the Story: Lessons for Academic-Activists}

Harvey's 2014 report on state-funded advocacy in Ireland concludes that "the documentary record uncovered a range of experiences from the positive to the negative, with many points along that spectrum, with the state's behaviour often inconsistent" $(2014$, p. 10). It seems, therefore, that there are no simple answers to the question of what impact state funding has on activism. Nevertheless, as I hope to have shown, the engagement of Irish CSO-activists in self-reflection and dialogue with academic commentators has identified three key challenges. Activists who are aware of the risks that attend state funding will be in a better position to manage the potential pitfalls and to know when to avoid such funding altogether. In particular, activists need to (a) defend the mandates given to them by their constituents, and avoid being driven toward activities that betray or distract them from those mandates; (b) maintain accountability to the groups on whose behalf they are working as well as to the state agencies that are funding them; and (c) foster collaborations with other activists in pursuit of progressive social change. These challenges are relevant to all activists, but have particular salience for those whose activism occurs in a context of public funding, including academics.

In Ireland (and Canada) university teaching and research remains largely funded by the public purse (Butler \& Mulgan, 2013; Lynch, 2014). In the academic literature on university funding, public financial support is generally regarded as enabling rather than hampering academic freedom, including the autonomy to engage in activist activities of one's choosing. In this context, two recent changes to Irish university funding formulas are 
alarming to many scholars. First, the Irish state is in the midst of a process of reducing the percentage of university operating costs it is willing to bear. This means that while universities continue to depend on state funding, they are now also increasingly reliant on other sources of funding, including from the corporate sphere. According to Lynch (2014, p. 150), this threatens to create a situation where the "interests of the university become synonymous with powerful vested interests", thereby undermining the broader public purpose of universities and making certain types of activist scholarship less possible. The second cause for alarm to activist scholars is that state funding of university-based research is becoming increasingly targeted to narrowly focused research agendas related to innovation, commercialization, and the 'knowledge economy' (Lolich, 2011). As Lolich (2011) contends, in this neoliberal funding context, "education is framed in economic terms while ignoring other important aspects of educating for affective citizenship" (p. 282), including "criticality, solidarity and social engagement" (p. 271). Scholar activism in support of progressive social change is disadvantaged in such a funding climate.

Both of these developments - greater reliance on non-government sources, and greater government control over how public funding to universities is targeted - increase the extent to which university-based activism is threatened by the same challenges outlined above for the CSO sphere. Yet, academic literature has been slow to recognize these commonalities, either in its critique of state-funded CSO-activism or in its analyses of universities' evolving funding circumstances. Just as CSO-activism is more effective when organizations collaborate to achieve progressive social change, so CSO- and university-based activism is likely to be more effective if these two activist spheres learn from each other's experiences and work together to overcome common challenges, including the challenges implicit in government funding.

Although I have been surprised by the tone of much of the academic commentary regarding state funding of CSO activism, I acknowledge that my own activist experiences shape my knowledge formation (Hanrahan, Cooper, \& Burroughs-LANGE, 1999, p. 405). In particular, I come to the issues addressed in this article with two overarching convictions. First, I do not accept that the inequalities we face today are inevitable or necessary; rather, inequality is a consequence of how we choose to organize society. For me, a more participatory and inclusive democracy is an expression of and route toward greater equality. Second, I am convinced that CSOs make an important contribution to democracy; however, in order to do so they need resources that enable them to build relationships, expertise, and know-how. Pragmatically, state funding is likely to continue to play role in responding to this resourcing dilemma.

A further question of positionality is the impact of my own direct experiences of state funding. On the one hand, I have seen state funding explicitly support the four activities that I identify in this article as nourishing democracy. On the other, I have also experienced the negative consequences 
of 'qualified' funding and funding cuts. In paid staff roles, and as a volunteer board member, I have been given specific direction from state funders with regard to permissible activity, experienced the challenge of balancing the burden of funder accountability while trying to remain accountable to my organizations' constituents, and have seen first-hand the tensions that arise between CSOs as they compete for diminishing financial resources. As director of The Advocacy Initiative (a privately funded project) I managed research on the relationship between state funding and CSO advocacy and spoke to many actors within CSOs, as well as within political institutions, who had a broad range of experiences vis-à-vis both the positive and negative implications of state funding. Consequently, I am convinced that the relationship between state funding and democratic contribution is an important one, but it is complex and evades simple conclusions.

\section{Acknowledgements}

I wish to sincerely thank the special issue editors, Sandra Smeltzer and Sara Cantillon, for their ongoing support during the development of this article. I would also like to thank David Butz, the journal's Editor-in-Chief, for his guidance and insight. The energy and commitment that each brought to this process is encouraging to me both as an activist and as an aspiring academic.

\section{References}

Adshead, M. (2011). An advocacy coalition framework approach to the rise and fall of social partnership. Irish Political Studies, 26(1), 73-93.

Airey, S. (2006). Communities, voices and change: A report on the policy work of CDPs, FRCs and partnerships. Dublin: Combat Poverty Agency. Retrieved from http://www.combatpoverty.ie/publications/CommunitiesVoicesAndChange_2006.pdf

Allen, M. (2013). Barriers and barricades: Exploring the challenges of building social movements for people who are poor. In D. O’Broin \& M. Murphy (Eds.), Politics, participation \& power: Civil society and public policy in Ireland (pp. 68-82). Dublin: Glasnevin Publishing.

Baker, J., Lynch, K., Cantillon, S., \& Walsh, J. (2009). Equality: From theory to action. Basingstoke: Palgrave Macmillan.

Balassiano, K., \& Chandler, S.M. (2009). The emerging role of nonprofit associations in advocacy and public policy: Trends, issues, and prospects. Nonprofit and Voluntary Sector Quarterly, 39(5), 946-955.

Baur, D., \& Schmitz, H.P. (2011). Corporations and NGOs: When accountability leads to cooptation. Journal of Business Ethics, 106(1), 9-21.

Breen, O. (2012). Too political to be charitable? The Charities Act 2009 and the future of human rights organisations in Ireland. Public Law, 2012(2), 268-287.

Butler, P., \& Mulgan, R. (2013). Can academic freedom survive performance based research funding? Victoria University of Wellington Law Review, 44(3/4), 487-520.

Calhoun, C. (2009). Academic freedom: Public knowledge and the structural transformation of the university. Social Research: An International Quarterly, 76(2), 561-598.

Carter, A., \& Stokes, G. (Eds.). (2002). Democratic theory today: Challenges for the 21st century. Cambridge: Polity Press.

Studies in Social Justice, Volume 9, Issue 2, 231-243, 2015 
Clark, J. (2011). Civil Society in the age of crisis. Journal of Civil Society, 7(3), 241-263.

Coelho, V.S.P., \& Von Lieres, B. (Eds.). (2010). Mobilizing for democracy: Citizen action and the politics of public participation. London: Zed Books.

Cox, L. (2010, May 17). Another world is under construction? Social movement responses to inequality and crisis. Irish Left Review. Retrieved from http://www.irishleftreview.org/category/articles/

Croteau, D. (2005). Which side are you on? The tension between movement scholarship and activism. In W. Hoynes, C. Ryan \& D. Croteau (Eds.), Rhyming hope and history: Activists, academics, and social movement scholarship (pp. 20-40). Minneapolis: University of Minnesota Press.

Crowley, N. (2012). Lost in austerity: Rethinking the community sector. Community Development Journal, 48(1), 151-157.

Crowley, N. (2013, June). There's something about government and Travellers. Village. Retrieved from http://www.villagemagazine.ie/index.php/2013/07/theres-something-aboutgovernment-and-travellers/

Dahl, R.A. (1989). Democracy and its critics. New Haven: Yale University Press.

Daly, S. (2007). Mapping civil society in the Republic of Ireland. Community Development Journal, 43(2), 157-176.

Department of the Environment, Community and Local Government. (2015). Scheme to support national organisations: Review of public funding of national organisations in receipt of bridging funding. Dublin: Government of Ireland. Retrieved from http://www.environ.ie/community/community-and-voluntary-supports/scheme-supportnational-organisations/2015-review-public

Department of the Environment, Community and Local Government. (2015). Report of the forum on philanthropy and fundraising. Dublin: Government of Ireland. Retrieved from http://www.philanthropy.ie/good-giving/forum-on-philanthropy/

Department of the Taoiseach. (2005). Reaching out - Guidelines on consultation for public sector bodies. Dublin: Government of Ireland. Retrieved from http://www.per.gov.ie/en/

Diamond, L.J. (1999). Developing democracy: Toward consolidation. Baltimore: Johns Hopkins University Press.

Donnelly-Cox, G., \& Cannon, S.M. (2010). Responses of non-profit organisations to altered conditions of support: The shifting Irish landscape. Voluntary Sector Review, 1(3), 335353.

Edwards, M. (2009). Civil society. Oxford: Polity Press.

Edwards, M., \& Hulme, D. (1996). Too close for comfort? The impact of official aid on nongovernmental organizations. World Development, 24(6), 961-973.

Fernando, J.L., \& Heston, A.W. (1997). Introduction: NGOs between states, markets, and civil society. Annals of the American Academy of Political and Social Science, 554, 8-20.

Flood, M., Martin, B., \& Dreher, T. (2013). Combining academia and activism, common obstacles and useful tools. Australian Universities Review, 55(1), 17-26.

Geller, S., \& Salamon, L. (2007). Nonprofit advocacy: What do we know? (Working Paper Series No. 22). John Hopkins University, Baltimore: Centre for Civil Society Studies. Retrieved from http://ccss.jhu.edu/wpcontent/uploads/downloads/2011/09/CCSS_WP22_2007.pdf

Government of Ireland. (2000). Supporting voluntary activity - A white paper on a framework for supporting voluntary activity and for developing the relationship between the state and the community and voluntary sector. Dublin: Government of Ireland.

Government of Ireland. (2000). Programme for prosperity and fairness, 2000-2003. Dublin: Government of Ireland. Retrieved from http://www.taoiseach.gov.ie/upload/publications/310.pdf

Government of Ireland. (2003). Sustaining progress: Social partnership agreement 2003-2005. Dublin: Government of Ireland. Retrieved from http://www.taoiseach.gov.ie/upload/SustProgagri.pdf

Government of Ireland. (2006). Towards 2016: Ten-year framework social partnership agreement 2006-2015. Dublin: Government of Ireland. Retrieved from 
http://www.taoiseach.gov.ie/attached_files/Pdf\%20files/Towards2016PartnershipAgreeme nt.pdf

Government of Ireland. Charities Act 2009. Dublin: Government of Ireland. Retrieved from http://www.irishstatutebook.ie/eli/2009/act/6/enacted/en/html

Grant Thornton. (2012). Not-for-Profit survey 2012: The opinions and concerns challenging Ireland's Not-for-Profit sector. Dublin, Ireland. Retrieved from http://www.grantthornton.ie/industry/not-for-profit/

Hanrahan, M., Cooper, T., \& Burroughs-LANGE, S. (1999). The place of personal writing in a $\mathrm{PhD}$ thesis: Epistemological and methodological considerations. International Journal of Qualitative Studies in Education, 12(4), 401-416.

Harvey, B. (2012). Changes in employment and services in the voluntary and community sector in Ireland, 2008-2010. Dublin: ICTU Community Sector Committee.

Harvey, B. (2013). Funding dissent: Research into the impact on advocacy of state funding of voluntary \& community organisations. Dublin: The Advocacy Initiative. Retrieved from http://www.advocacyinitiative.ie/resource/funding-dissent-research-impact-advocacy-statefunding-voluntary-community-organisations

Harvey, B. (2014). Government funding \& social justice advocacy: “Are we paying for that?" (pp. 1-76). Dublin: The Advocacy Initiative. Retrieved from http://www.advocacyinitiative.ie/resource/are-we-paying-government-funding-and-socialjustice-advocacy

Hughes, I., Clancy, P., Harris, C., \& Beetham, D. (2007). Power to the people? Assessing democracy in Ireland. Dublin: TASC at New Island.

Hulme, D., \& Edwards, M. (Eds.). (1997). NGOs, states and donors: Too close for comfort? London: Macmillan.

INKEX. (2012). Irish nonprofits: What do we know? Dublin: Irish Nonprofits Knowledge Exchange. Retrieved from http://benefacts.ie/wp-content/uploads/2015/06/Irish-NonprofitsWhat-do-we-know-Report-January-20121.pdf

Kamat, S. (2004). The privatization of public interest: Theorizing NGO discourse in a neoliberal era. Review of International Political Economy, 11(1), 155-176.

Keane, J. (2012, December 14). By the people. Financial Times. Retrieved from http://www.ft.com/intl/cms/s/2/adfc52a6-438f-11e2-a48c00144feabdc0.html\#axzz2HoDm9x36

Keenan, O. (2008). Relationships and representation, challenges and opportunities for the voluntary and community sector in Ireland. Paper presented at the Summer School, Centre for Nonprofit Management, Trinity College Dublin. Retrieved from http://www.advocacyinitiative.ie/resource/relationships-and-representation-2008

Kirby, P. (2010). Civil society, social movements and the Irish state. Irish Journal of Sociology, $18(2), 1-21$

Kirby, P., \& Murphy, M. (2009). State and civil society in Ireland: Conclusions and mapping alternatives. In D. Ó Broin \& P. Kirby (Eds.), Power, dissent and democracy: Civil society and the state in Ireland (pp. 143-159). Dublin: A. \& A. Farmar.

Lang, S. (2013). NGOs, civil society, and the public sphere. Cambridge: Cambridge University Press.

Larragy, J. (2006). Origins and significance of the community and voluntary pillar in Irish social partnership. The Economic and Social Review, 37(3), 375-398.

Larragy, J. (2014). Asymmetric engagement: The community and voluntary pillar in Irish social partnership. Manchester; New York: Manchester University Press.

Lolich, L. (2011). ... and the market created the student to its image and likening. Neo-liberal governmentality and its effects on higher education in Ireland. Irish Educational Studies, $30(2), 271-284$

Lynch, K. (2014). New managerialism, neoliberalism and ranking. Ethics in Science and Environmental Politics, 13(2), 141-153.

Mair, P. (2005). Democracy beyond parties (CSD Working Papers). University of California. Retrieved from http://escholarship.org/uc/item/3vs886v9

McCarthy, J.D., \& Zald, M.N. (1977). Resource mobilization and social movements: A partial theory. American Journal of Sociology, 82(6), 1212-1241.

Studies in Social Justice, Volume 9, Issue 2, 231-243, 2015 
Meade, R. (2005). We hate it here, please let us stay! Irish social partnership and the community/voluntary sector's conflicted experiences of recognition. Critical Social Policy, 25(3), 349-373.

Meade, R. (2012). Government and community development in Ireland: The contested subjects of professionalism and expertise. Antipode, 44(3), 889-910.

Minkoff, D.C. (2002). The emergence of hybrid organizational forms: Combining identity-based service provision and political action. Nonprofit and Voluntary Sector Quarterly, 31(3), 377-401.

Murphy, M. (2002). Social partnership - is it "the only game in town"? Community Development Journal, 37(1), 80-90.

Murphy, M. (2009). Globalisation and Irish civil society. In D. Ó Broin \& P. Kirby (Eds.), Power, dissent and democracy: Civil society and the state in Ireland (pp. 34-47). Dublin: A. \& A. Farmar.

Murphy, M. (2013). Participating in popularising policy alternatives: A case study of Claiming Our Future. In D. O’Broin \& M. Murphy (Eds.), Politics, participation \& power: Civil society and public policy in Ireland (pp. 113-123). Dublin: Glasnevin Publishing.

National Economic and Social Council (NESC). (2005). The developmental welfare state. Retrieved from http://www.nesc.ie/en/publications/publications/nesc-reports/thedevelopmental-welfare-state/

O’Dwyer, B., \& Unerman, J. (2008). The paradox of greater NGO accountability: A case study of Amnesty Ireland. Accounting, Organizations and Society, 33(7-8), 801-824.

Popplewell, R. (2013). Responding to the crisis: Understanding the effects of political and economic crisis on civil society in the Republic of Ireland. INTRAC. Retrieved from www.intrac.org

Post, R., \& Rosenblum, N.L. (2002). Introduction. In N.L. Rosenblum \& R. Post (Eds.), Civil society and government (pp. 1-25). Princeton: Princeton University Press.

Prizeman, G., \& McGee, S. (2009). Charitable fundraising in an economic downturn: The first annual report on income and fundraising activity in Irish charities. Dublin: Irish Charities Tax Research Ltd., The Ireland Funds, Centre for Nonprofit Management, Trinity College. Retrieved from http://www.siobhanmcgee.ie/Annual_Report_on_Income_and_Fundraising_Activity.pdf

Pyles, L. (2009). Neoliberalism, INGO practices and sustainable disaster recovery: A postKatrina case study. Community Development Journal, 46(2), 168-180.

Sawer, M., \& Jupp, J. (1996). The two-way street: Government shaping of community-based advocacy. Australian Journal of Public Administration, 55(4), 82-99.

Shaver, S. (2015). How a study lost its funding: Jean Martin and public knowledge of the refugee experience. Journal of Sociology, 51(2), 285-298.

Smith, G. (2009). Democratic innovations: Designing institutions for citizen participation. Cambridge: Cambridge University Press.

Snowdon, C. (2012). Sock puppets: How the government lobbies itself and why (Discussion paper No. 39). London: The Institute of Economic Affairs. Retrieved from http://www.iea.org.uk/sites/default/files/publications/files/DP_Sock\%20Puppets_redesigne d.pdf

Suzuki, D., \& Mayorga, E. (2014). Scholar-activism: A twice told tale. Multicultural Perspectives, 16(1), 16-20.

Wallace, T. (2004). NGO dilemmas: Trojan horses for global neoliberalism. Socialist Register, 40. Retrieved from http://socialistregister.com/index.php/srv/article/view/5818\#.VtQg4cftM4

Walsh, K. (2014). Pulling together: A synthesis of the work of The Advocacy Initiative 20102014. The Advocacy Initiative. Retrieved from http://www.advocacyinitiative.ie/resource/pulling-together-synthesis-work-advocacyinitiative-2010-2014

Wampler, B. (2008). When does participatory democracy deepen the quality of democracy? Lessons from Brazil. Comparative Politics, 41(1), 61-81. 